\title{
ARTE MODERNA E ARTE JAPONESA: \\ ASSIMILAÇÕES DA ALTERIDADE
}

\section{José D'Assunção Barros ${ }^{1}$}

RESUMO: Este artigo busca esclarecer e discutir as relações entre a Arte Moderna e a arte japonesa. Mostra-se como, em contraste com a estética e com os modos de representação clássico e romântico, um dos pontos de ruptura de toda uma série de artistas ocidentais, que já podem ser classificados como modernos, foi precisamente uma nova postura com relação à Arte de outros povos, sendo que neste aspecto a assimilação da arte japonesa teria desempenhado um papel particularmente exemplar e transformador para a renovação da Arte Moderna ocidental desde a época dos pintores impressionistas..Neste sentido, demonstra-se como, a partir desta assimilação de alteridades artísticas como a japonesa, os modernos artistas ocidentais conseguiram recriar a sua própria arte.

Palavras-chave: Arte Moderna, Alteridade; Arte Japonesa; Imagem; Representação.

ABSTRACT: This article attempts to clarify and discuss the relations between Modern Art and the Japanese art. The intent is to show how, in contrast do the aesthetic and ways of representation of the classical and romantic arts, one of the points of rupture of several occidental artists, which can be yet classified as moderns, was precisely a new posture in relation to the Art of the other peoples, considering that, in this aspect, the assimilation of the Japanese art would had a exemplary and transformer importance for the renovation of the modern occidental art since the epoch of the impressionists painters. In this sense, it is showed how, working with an assimilation of alterities as the Japanese, the modern occidental artists had success in recreate his own art.

Key words: Modern Art; Alterity; Japanese Art; Image; Representation.

1 Doutor em História Social pela Universidade Federal Fluminense (UFF). Professor da Universidade Federal Rural do Rio de Janeiro, nos Cursos de Mestrado e Graduação em História. Entre as obras mais recentes, destacam-se os livros $O$ Campo da História (Petrópolis: Vozes, 2004), O Projeto de Pesquisa em História (Petrópolis: Vozes, 2005), Arte Moderna e Alteridade (Vassouras: LESC, 2005) e Cidade e História (Petrópolis: Vozes, 2007). 
Desde fins do século XIX, os artistas modernos do Ocidente vêm renovando a sua Arte a partir do contato com a Alteridade - do contato com este "outro" (considerado do ponto de vista ocidental) que até as últimas gerações românticas era ainda visto como o oriental exótico, o africano primitivo, o nativo ingênuo do Brasil ou da Polinésia. Particularmente a arte oriental, e ainda mais enfaticamente a arte dos antigos gravuristas japoneses, contribuiu em diversos momentos com uma excepcional possibilidade de renovação estética, técnica e conceitual para os artistas ocidentais que construíram a Arte Moderna desde fins do século XIX e no decurso do século XX.

O ensaio que aqui se apresenta partirá da hipótese de que é possível perceber a história da Arte Moderna, desde fins do século XIX, do ponto de vista da sua ruptura com a Arte Romântica e com o padrão clássico de representação em um aspecto bastante específico: a sua postura diante da Alteridade. Conforme veremos neste ensaio, se a alteridade fora relativamente desconsiderada pelos estilos neoclássicos (século XVIII), ela já passa a ser uma questão bastante importante para os artistas românticos. Contudo, enquanto os artistas românticos encantaram-se com a alteridade representada por outras épocas (sobretudo a medieval) e por outros povos (orientais, islâmicos, indígenas), sempre do ponto de vista de uma cultura que se pretende superior e encara o outro da perspectiva do exotismo ou da excitação diante do diferente, já os artistas modernos efetivamente se deixaram penetrar por esta Alteridade, aprendendo com a arte dos outros povos uma maneira de superar e ultrapassar os seus antigos padrões de representação e a sua própria concepção sobre o que é a arte. Desta maneira, postula-se aqui, os românticos, ao representarem cenas orientais e primitivas em suas telas, estavam apenas "reconstruindo o outro" a partir de seus próprios parâmetros e sistemas de representação; já os modernos literalmente reconstruiram-se, a si mesmos enquanto artistas e à sua própria arte, a partir deste outro.

As artes imagéticas japonesas constituíram certamente a primeira grande alteridade artística que impressionou fortemente os artistas modernos do ocidente. Em certo sentido, a sua assimilação pelos pintores europeus representa mesmo um ponto de virada na arte ocidental. Saturados de padrões de representação que vinham se desenvolvendo desde a Arte Renascentista, de técnicas há muito utilizadas nas várias esferas da produção artística, e também saturados de uma forma específica de ver o mundo que se transpunha sintomaticamente para as obras de arte, estes artistas ocidentais modernos deixaram-se invadir, em momentos distintos da sua história, por esta Alteridade trazida pelos artistas visuais japoneses, que acabaram abrindo caminho para as outras alteridades orientais (chinesa, persa, islâmicas, oceânicas), e depois para as alteridades africanas, que iriam influenciar fortemente os artistas cubistas e fauvistas.

Antes de mais nada, convém considerar que os caminhos das culturas ocidentais em direção ao "outro" vieram a constituir a base para um movimento 
bastante amplo, que estende sua abrangência às várias formas de expressão e gêneros artísticos da arte ocidental. Podemos perceber este grande movimento na Pintura, na Escultura, na Música, na Literatura. E podemos também associar esta retomada mais recente das outras culturas a um fenômeno mais geral - que se esbate na própria 'crise de descentramento' do homem ocidental, no momento em que este começa a questionar sua visão etnocêntrica do mundo e a idéia evolutiva de que ele mesmo era o ponto mais avançado e civilizado a ser atingido pelas culturas que antes considerava primitivas ou exóticas. Ao menos entre os antropólogos, historiadores e artistas, este caminho do descentramento e do reconhecimento criativo do "outro" pode se confrontar nos dias de hoje com projetos que - a despeito da consciência $\mathrm{da}$ insustentabilidade etnocêntrica que foi consagrada em um plano intelectual mais elevado - ainda persiste em processos políticos, militares e econômicos de dominação e sujeição que por vezes chegam a ameaçar a paz mundial.

Mas a Arte Moderna descobriu o "outro" - ou, é o que pretendemos discutir, fez-se mesmo a partir deste "outro" Por outro lado, antes de compreendermos isto, devemos lembrar que o interesse e fascínio pelo "outro" nas sociedades européias (e americanas, por extensão) não constituiu propriamente uma novidade que teria aflorado apenas às portas da modernidade artística.

Essa atração, de diversas maneiras, vinha desde tempos mais remotos caminhando a par do "medo do Outro", do seu estranhamento, da vontade de submetêlo-e a sua história é tão extensa quanto complexa. Trata-se de uma história que também fala a respeito da invenção de uma certa imagem do Oriente que pôde contribuir para a construção da própria Identidade Ocidental - uma história que também inclui os grandes lances de um processo de legitimação da atitude colonizadora, onde não raro se transmite a idéia de que os povos exteriores à ocidentalidade não disporiam de todos os recursos para se auto-representar, devendo por isto ser representados. O Ocidente é então redesenhado, sob o pano de fundo do Oriente e das alteridades africanas, como o lugar da Racionalidade, da Ciência, da Civilização capaz de avaliar as outras - e portanto de representá-las².

Mas o nosso estudo irá se ater ao mundo da Arte, à Representação, aos processos de Representação que se dão na Arte, sendo possível examinar, além disto, como da Representação emerge a Abstração, esta interagindo com a primeira mas em outros momentos também a negando. A assimilação das alteridades artísticas à palheta de recursos e de posturas estéticas dos artistas ocidentais foi, conforme postulamos, o aspecto mais expressivo na construção de uma nova arte ocidental, que

2. A própria visão de um Oriente misterioso e prodigioso deve ser desmistificada relativamente ao seu ambíguo papel nos processos de colonização movidos desde a expansão colonialista por paises como a Inglaterra, França e Estados Unidos, e foi este o objetivo de Edward Said em uma obra que deve ser registrada como referência para os estudos a respeito da invenção de uma certa imagem de Oriente pelo Ocidente colonizador. A representação dos povos orientais teria sido, segundo o autor, de fulcral importância para a própria definição da identidade ocidental na legitimação de seus interesses colonialistas (SAID, 2001). 
logo passaria a ser denominada Arte Moderna. Para entender esta complexa questão, será necessário demarcar com toda a precisão possível a singularidade da assimilação e reelaboração da Alteridade pela arte Ocidental de fins do século XIX e da primeira metade do século XX. A princípio, esta singularidade pode ser iluminada a partir do seu contraste com o interesse da Arte Romântica pela alteridade, que tinha ocorrido nas décadas anteriores mas por um viés bem distinto.

De fato, também os artistas românticos haviam se interessado pelo Oriente, pela África e pela América. Delacroix (1798-1863) e tantos outros pintores haviam retratado personagens e ambientes orientais, haréns turcos, odaliscas e cenas islâmicas; e a Literatura ocidental já tinha à mesma época descoberto estes mesmos temas, lançando um olhar para as outras culturas do seu tempo ao mesmo tempo em que lançavam o outro olhar para antigos mundos do seu passado histórico que haviam sido desdenhados pelos pintores neoclássicos - como a enigmática Idade Média, por exemplo. No Brasil do século XIX, e na América de modo geral, pintoresviajantes vindos da França, da Inglaterra, da Itália, da Alemanha e de outras partes da Europa buscaram avidamente novos ambientes para serem retratados e descritos. Contudo, o que buscavam estes diversos artistas no Oriente, na África e na América? Eles buscavam o "exótico", a alteridade como elemento para surpreender, em alguns casos para questionar uma realidade que os desapontava ou da qual eram críticos, em outros casos para exercer um trabalho de erudição sobre as exóticas civilizações orientais ou sobre os "selvagens" povos nativos da África e da América. Conforme se vê, o interesse da Arte e da Literatura Romântica pelas culturas não-ocidentais era sobretudo um interesse temático, às vezes motivado pela curiosidade de antiquários que havia sido trazida pelo Historicismo tão típico do século XIX, às vezes motivado por uma vontade de evasão da dura realidade da qual muitos artistas eram críticos, ou ainda por uma vontade de vivenciar intensamente as fortes emoções da alteridade.

Examinemos agora uma situação bem distinta. O que buscaram os movimentos modernos nestas outras culturas e civilizações, que os diferencia tão radicalmente da postura romântica?. Esta indagação remete a uma questão complexa que se refere a uma delimitação (talvez impossível) dos primórdios da modernidade e dos movimentos que já podem ser legitimamente categorizados como "modernos" Embora esta seja uma questão polêmica e que pode ser discutida, pelo menos para o aspecto aqui dissertado será bastante oportuno considerar a modernidade ou a prémodernidade dos Impressionistas, pois eles foram certamente os primeiros artistas a examinarem as culturas não-ocidentais de uma nova maneira que não a meramente pautada pela sensação do "exótico" Logo veremos que, na sua assimilação da arte oriental - em especial da arte japonesa, que é o nosso interesse mais específico neste momento - os impressionistas buscavam não tanto uma renovação de temas, embora isto também pudesse ocorrer lateralmente, mas principalmente novos padrões de expressão e representação, novas possibilidades técnicas e materiais, ou até mesmo novas maneiras de conceber a arte. 
Esta mesma busca de novos meios e padrões que pudessem renovar a arte, mais do que os temas, estaria também por trás do interesse de alguns artistas modernos por culturas antigas que não a civilização Greco-Romana - esta que fora a matriz da tradicional concepção artística do Ocidente através de sua retomada renascentista e de seus desenvolvimentos posteriores. $\mathrm{O}$ que os artistas do período moderno ou pré-moderno buscavam na alteridade cultural de sua própria época, ou na alteridade histórica de civilizações como o Antigo Egito, era sobretudo uma possibilidade de renovar a arte a partir dos seus próprios meios. Pela primeira vez os artistas ocidentais se interessavam mais sistematicamente não pelo "outro cultural" como tema para a sua arte sempre ocidental - mas sim pela própria arte deste outro. Estes artistas motivaram-se simplesmente a aprender algo com a Arte do Oriente, da África, da América nativa e da Oceania. Eles ousaram renovar a sua arte a partir de um exame atento da Arte de outros povos, e não se limitaram simplesmente a utilizar temas oriundos destes povos para tratá-los à maneira ocidental tradicional. A Arte Japonesa, conforme veremos, foi o ponto de partida desta nova postura. A sua assimilação pelos artistas ocidentais abre efetivamente novos caminhos, e o movimento dentro da arte ocidental que inicia este processo é o Impressionismo.

Existem razões históricas que favoreceram, em fins do século XIX, o contato mais sistemático entre a civilização ocidental e a arte que se fazia no extremooriente. Pode ser citado por exemplo um tratado comercial entre a França e o Japão no ano de 1858 , que facilitou muito o acesso dos franceses a produtos japoneses, e também é imprescindível lembrar uma mostra internacional que ocorrera no ano de 1867 - na qual o Japão se fez presente com inúmeras peças de cerâmicas e xilogravuras (ukiyo-e). Mas, tal como já foi dito, o interesse pelo Extremo Oriente então despertado nos artistas impressionistas - distintamente do mero interesse pelo exótico despertado nas pessoas comuns da mesma época - deve ser atribuído antes de mais nada a um forte interesse de renovação estética e técnica, de modo que o acesso facilitado a peças oriundas do extremo oriente apenas entrou basicamente como um elemento dinamizador deste processo. Dito de outra forma, os artistas impressionistas buscaram a arte japonesa porque precisaram dela, e não porque tiveram repentino acesso a elas através do comércio de produtos orientais.

Um dos pioneiros na reelaboração de uma influência oriental na pintura impressionista foi seguramente Claude Monet (1840-1926), que acentuara seu interesse pela arte japonesa a partir de 1866 - ano em que viajara para a Holanda. Este país, diga-se de passagem, desde o século XVI já cultivava uma ligação comercial bastante significativa com o Oriente, de modo que mesmo Rembrandt (1606-1669) - um pintor barroco do século XVII - já havia se interessado discretamente por estampas japonesas, inspirando-se para algumas de suas gravuras na economia de traços e na ocorrência de espaços vazios que era bastante típica das aguadas japonesas (HASHIMOTO, 2002). Desta forma, é bastante sintomático que Monet tenha acentuado seu interesse pelas estampas japonesas durante sua estadia na Holanda, se 
bem que o pintor francês tenha declarado em uma entrevista depois publicada que já conhecia a pintura japonesa antes desta data (MACHADO, 1982: 13). De qualquer maneira, ele confirma que foi na Holanda que conseguiu adquirir um relevante lote de estampas japonesas.

É também de 1867 um quadro igualmente sintomático de Monet - o "Terasse à Sainte Adresse" - onde já aparecem aspectos inspirados no padrão oriental. Entre estes elementos, podemos indicar a sua representação das ondas do Mar, tratadas com um certo decorativismo estático que conferem a esta pintura a sensação de estarmos diante de um cenário de Teatro. De igual maneira, a par de uma perspectiva ocidental empregada no sub-ambiente pictórico do Terraço, ele recorre a uma visão tipicamente oriental quando passa à representação do Céu e do Mar, situando todos os seus elementos num mesmo plano. Observa-se ainda que as figuras humanas neste quadro de Monet são bem pouco individualizadas, de modo que elas assumem um papel fundamentalmente plástico na composição (MACHADO, 1982: 13).

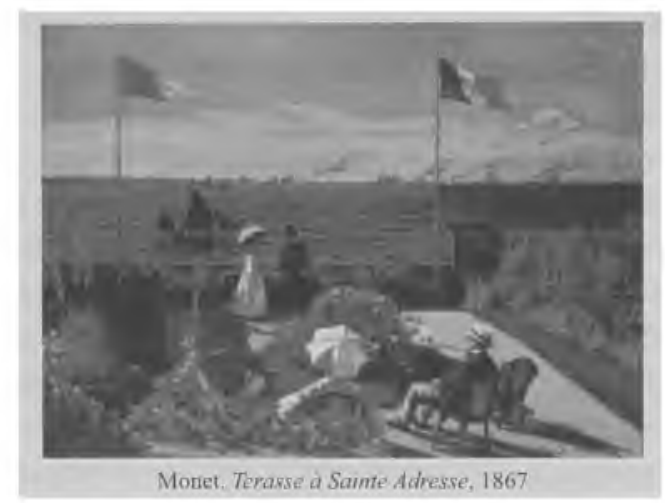

Este quadro dificilmente seria explicável sem a inspiração da arte oriental, posta a dialogar com elementos mais marcadamente ocidentais. A apropriação artística das estampas japonesas por Monet e outros impressionistas foi de fato uma grande fonte de renovações, e será útil entender em linhas gerais o que caracterizava estas estampas - tanto do ponto de vista de seus materiais como do ponto de vista de suas técnicas e formas de construção das imagens.

As gravuras denominadas ukiyo-e (palavra que poderia ser traduzida como "mundo flutuante") surgem no Japão ainda no século XVII - no decurso do chamado período Edo (1603-1868) - e adquirem um grande impulso com a arte de Hishikawa Moronobu (1618-1694). As estampas do "mundo flutuante" estavam na sua origem limitadas ao contraste entre o preto e o branco, mas logo foram incorporando outras cores até atingir uma policromia bastante rica.

Entre os temas preferidos de Moronobu destacam-se a representação de flores, de pessoas passeando à noite à beira do rio Sumida, da figura feminina, ou de pessoas 
entretendo-se com pequenos jogos. Mas, desde já, é muito importante ressaltar que as figuras nas estampas de Moronobu assumem uma função fundamentalmente plástica na composição. Essa tendência prossegue com artistas posteriores, sendo oportuno lembrar o nome de Harunobu, que nos anos 1760 introduz a cor em diferentes placas de madeira ${ }^{3}$ As estampas policrômicas transferidas para placas de madeira passam a permitir a impressão em quantidades maiores, daí originando-se o gênero das xilogravuras. De todo modo, para a questão que presentemente nos interessa, é fundamental ressaltar que as figuras nas estampas japonesas mostram-se em geral pouco individualizadas, o que reforça a sua função como elementos da composição entre outros - pretextos para o desenho e para o trabalho com a cor, e não tentativas de imitação da realidade ou da natureza à maneira ocidental. Mais tarde surgiriam outros mestres de singular importância, e que tiveram seus trabalhos bem difundidos no Ocidente, como foi o caso de Hokusai (1760-1849) - autor da célebre gravura "A Onda"

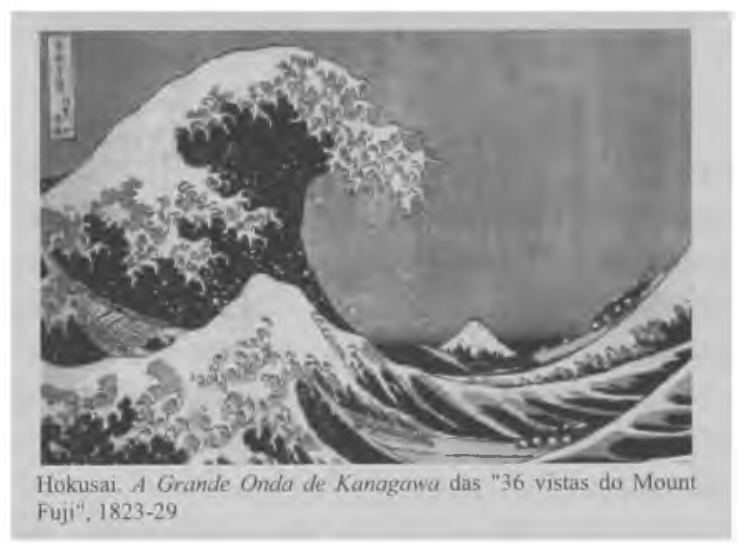

Do ponto de vista da concepção de arte, os artistas japoneses oriundos da arte Edo estavam atentos a alguns princípios estéticos fundamentais - como a "myabi", que significa algo como "elegância refinada", a "wabi" (prazer da tranqüilidade), a "sabi" (simplicidade elegante), e o "mono no aware" (phatos da natureza). Estes princípios viriam a calhar para a estética de alguns dos pintores impressionistas, particularmente para o seu caráter contemplativo e seu refinamento intimista, e não é de surpreender que as estampas japonesas tenham sintonizado tão bem com as suas aspirações estéticas.

Podemos neste ponto retomar a questão da assimilação da alteridade japonesa pelo Impressionismo. Outra pintura de Monet bem significativa nesta direção é "La Plage de Trouville" (1870), que alguns autores cotejam com uma das estampas japonesas

3 Harunobu foi o criador da técnica nishiki-e, expressão que significa "pintura-brocado", e que consiste em imprimir uma variedade de cores na mesma lâmina través do uso de pranchas sucessivas. 
da coleção do próprio Monet, atribuída a Utamaro Kitagawa (c.1797) (MACHADO, 1988: 8).

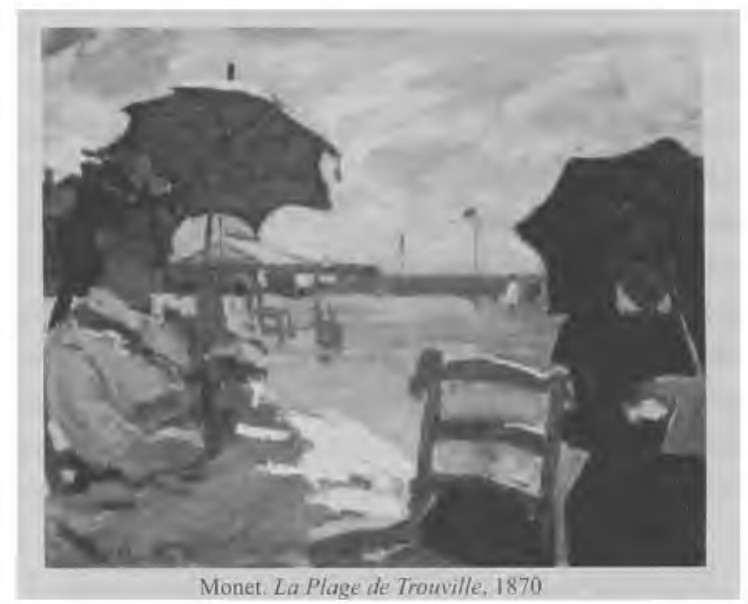

Como este quadro, poderiam ser citados outros exemplos de Monet e também de outros pintores como Degas, Guys, Redon, Tissot e, antes destes, Manet. Mas o que nos interessa por hora é destacar que Monet não vai buscar nestas estampas o tema (que ele na verdade adapta a motivos do Ocidente), mas sim novas técnicas de uso da perspectiva, de representação das figuras femininas de modo pouco individualizado - o que lhes confere um valor eminentemente plástico e não temático - bem como a representação de diversos elementos figurativos praticamente sem volume. Citaremos, por fim, o emprego de pinceladas largas, planas e espessas, que terminam por unificar a composição de uma maneira que à época era pouco empregada no Ocidente.

Assim como Monet, outro pintor da belle-époque que se inspirou na gravura japonesa para renovar a sua arte foi Toulouse-Lautrec (1864-1901). Ele acompanha Edgar Degas (1834-1917) na sua busca por uma nova economia de meios, e a aplica a um novo gênero que torna a sua arte singular e única: o cartaz. Foi precisamente com as gravuras japonesas que Toulouse-Lautrec percebeu o impacto impressionante que uma ilustração poderia trazer se a modelagem e o detalhamento fossem sacrificados em nome de uma audaciosa simplificação.

Os famosos cartazes de Toulouse-Lautrec, muitos deles desenhados para divulgação de espetáculos e cabarés parisienses, incorporam diversos elementos inspirados nas gravuras japonesas. Entre estes elementos destacam-se a simplificação bidimensional, à qual cada vez mais iriam se voltar os pintores modernos, e também a prática de cortar as cenas pelas bordas do quadro ou da ilustração. Os recursos para 
sugerir alguma espacialidade diante desta nova proposta de simplificação bidimensional também são muitas vezes inspirados nas estratégias imagísticas do gravuristas japoneses.

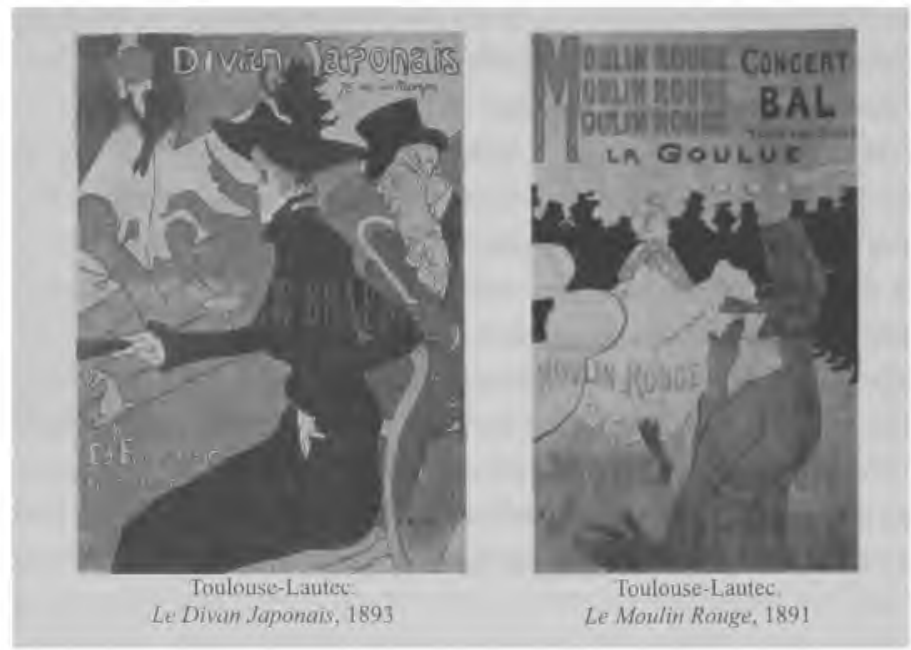

No quadro à direita - o primeiro cartaz de Toulouse-Lautrec para uma casa parisiense, no caso o famoso cabaré Moulin Rouge - vemos ao fundo algumas silhuetas negras de figuras humanas de diversos tamanhos que se contrapõem a um fundo mais claro. São elas, e as riscas inclinadas do assoalho que se dirigem para um improvisado ponto de fuga, que trazem uma sugestão de profundidade para um curioso diálogo com a simplificação bidimensionalizada de que Toulouse-Lautrec lança mão neste e em outros cartazes que primam por uma bem calculada economia

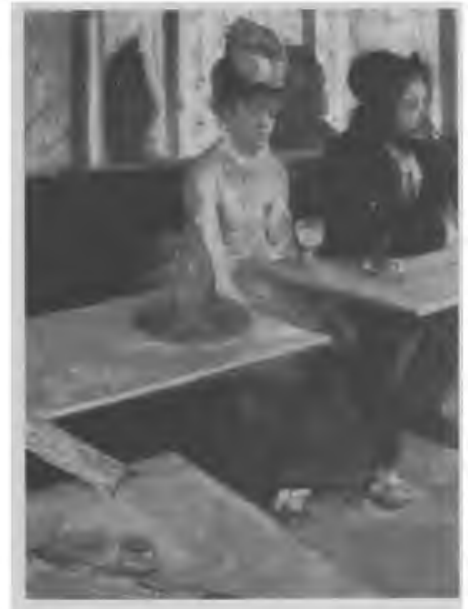

Edgar Degas. O Absinto, 1876. Óleo sobre Tela, $92 \times 68 \mathrm{~cm}$ de meios. Em ambos os exemplos acima destacados vemos também a liberdade tomada pelo pintor ao cortar a cena e as figuras pelas bordas dos quadros, ou então ao segmentá-las com objetos interpostos - tal como ocorre com as lâmpadas amarelas que recortam a imagem da dançarina do Moulin Rouge pela esquerda.

O recurso de cortar a figura com a borda do quadro também aparece, amiúde, em Edgar Degas (1834-1917) - outro pintor francês que aprendera com os japoneses a ultrapassar os lugares-comuns da pintura ocidental, entre estes a insistência em representar as figuras na sua inteireza, ou então focar as suas partes aparentemente mais relevantes.

O quadro "Absinto" (1876) é uma destas cenas incomuns em que o pintor rompe francamente 
com a organização convencional de imagens. Além de quase cortar uma das figuras pela borda direita do quadro, ele desenvolve uma lógica imagística bastante específica: leva o olhar do observador a se aproximar do melancólico casal - centro temático da composição embora deslocado para a direita do quadro - através de uma espécie de zigue-zague através de duas mesas vazias.

Além de não se deixar conduzir pelas convenções habitualmente aceitas por muitos dos pintores ocidentais e de não hesitar em cortar as figuras pela metade, Degas também ansiava por representá-las a partir de seus ângulos mais surpreendentes. $E$ era talvez para explorar melhor estas novas liberdades que escolhia com freqüência as cenas de balés, onde as figuras de dançarinas eram surpreendidas nas posições mais inesperadas, ou imobilizadas em pleno movimento, ou então representadas nas mais diversificadas atitudes - não raro ficando de fora do quadro partes dos seus corpos. Suas diversas cenas de Balé ilustram tanto a busca de um novo universo temático como uma orientação para a renovação dos meios da própria pintura, para um pouco além daquilo que vinham fazendo os impressionistas de seu tempo.

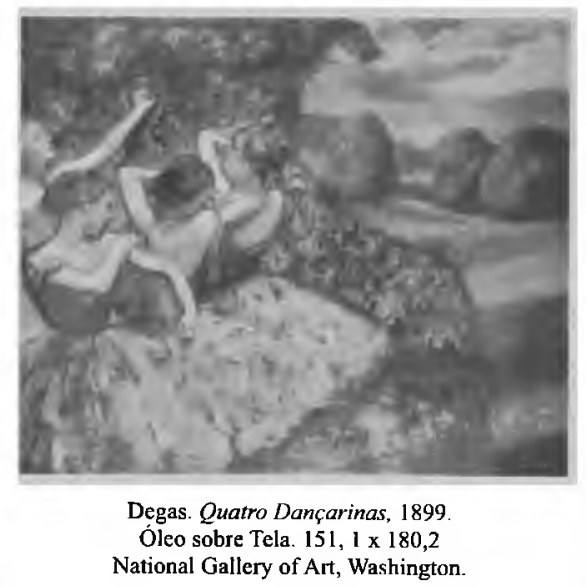

Não estamos longe, nestes criativos esforços de Degas e Toulouse-Lautrec em romper com os lugares-comuns pictóricos do Ocidente, das práticas de composição de imagens que há muito eram desenvolvidas pelos gravuristas japoneses - e foram estes que lhes deram os elementos para perceber que a Arte Ocidental estava repleta de lugares-comuns de que muitas vezes os pintores europeus já não se davam mais conta. Desta forma, uma cultura pictórica pôde iluminar a outra, e os pintores europeus dos últimos anos do século XIX puderam aprender novos caminhos que não teriam sido possíveis sem um salutar contato com a alteridade cultural. Não apenas os gravuristas japoneses já de muito costumavam cortar as imagens de figuras e objetos pelas bordas do enquadramento, ou mesmo através de objetos interpostos, como 


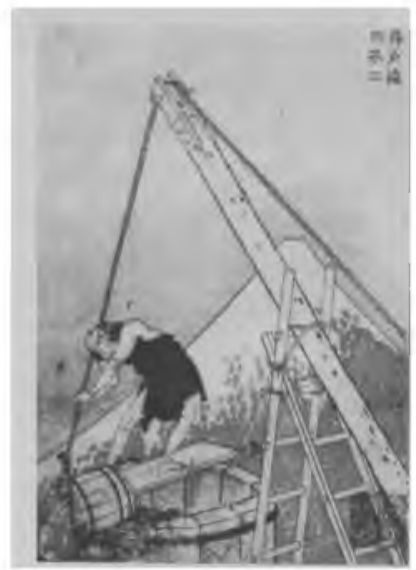

Hokusai. A Montanha Fuji vista de detrás de um fosso. 1834.

também eram extremamente hábeis em explorar uma imagem a partir de seu ângulo mais inesperado. Existe uma célebre série de xilogravuras japonesas intitulada Cem Vistas do Monte Fugi onde Hokusai, o mais célebre dos gravuristas japoneses de sua época, registra imagens de uma montanha japonesa a partir de ângulos diversos e de cenas inesperadas. Em uma delas, ele nos apresenta "A Montanha Fuji vista atrás de um poço" (1834).

Conforme pudemos verificar até aqui através dos exemplos ressaltados, o que pintores como Monet ou Toulouse-Lautrec buscavam nas estampas japonesas foi essencialmente da ordem da forma, da técnica, do uso da cor e do espaço, da concepção estética - e não do âmbito dos materiais temáticos, que era precisamente o que havia atraído alguns artistas românticos para uma assimilação de outro tipo do Oriente. Bem ao contrário, os impressionistas franceses de fins do século XIX estavam mais interessados no desenho franco e límpido das estampas japonesas, nas quais a elegância e força do conjunto eram freqüentemente acentuadas pela ocorrência de uma espécie de "claro-escuro descontínuo, oposto ao ocidental e fugindo ao modelado" (PEDROSA, 2000: 291). Em poucas palavras, eles interessaram-se em extrair da arte japonesa (e da chinesa) precisamente aquilo que lhes pôde ajudar a renovar seus meios e formas de expressão.

Nesta mesma direção, vale destacar a partir dos exemplos já indicados que a maior lição que os pintores impressionistas puderam extrair das estampas japonesas foi a possibilidade de compreenderem - a partir do contraste com uma arte não viciada pelas regras e convenções acadêmicas européias - o quanto estas convenções e lugares-comuns ainda persistiam entre eles, mesmo que disto nem sempre se dessem conta. Eles perceberam, com bastante clareza, que contemplar a Alteridade poderia ajudá-los a entender os limites de sua própria arte, e com isto impulsioná-los para a renovação.

Na mesma época em que os pintores impressionistas empreendiam as suas pesquisas no campo das artes visuais, a Música Impressionista também nos oferecia uma contribuição análoga através das composições mais modernas de Claude Debussy (1862-1918). Este compositor francês também se encantou com os modos musicais orientais, e vislumbrou a possibilidade de empregá-los para romper com 0 já saturado campo da tonalidade tradicional, que desde o período barroco limitava os músicos ocidentais a apenas dois padrões de escalas heptatônicas (os modos Maior e Menor). Ele investiu precisamente na utilização de antigos modos já esquecidos (os antigos modos medievais), mas também na utilização das escalas orientais de cinco sons, como por exemplo a escala pentatônica que, na teoria musical do ocidente, ficou 
conhecida como "modo javanês" Os resultados desta apropriação de modos orientais encontra-se em músicas como os "Arabescos" para piano ou o noturno "Nuages", para orquestra (1899). Seu sucessor no impressionismo musical francês, Maurice Ravel, segue por direções análogas, e o seu Quarteto de Cordas (1903) nos dá um bom exemplo do emprego da escala pentatônica oriental. De qualquer modo, é interessante ressaltar que estes músicos também empregaram meios e materiais das culturas musicais orientais para reformular a música moderna, e não para produzir meras referências temáticas, como o fez - à maneira romântica - Puccini na sua ópera "Turandot" (1924).

Voltando ao campo das artes visuais, é muito interessante notar que as mesmas estampas japonesas que haviam encantado os pintores impressionistas, como Monet e Sisley, continuaram se abrindo também à inspiração de outros artistas e movimentos, mas agora através de novos aspectos igualmente fundamentais para a revolução dos meios de representação e expressão, que não os antes destacados para o caso dos impressionistas. Assim, o que seduz Van Gogh (1853-1890), os fauvistas representados por Derain e Matisse, ou os pontilhistas liderados por Seurat e Signacpintores que adentram mais ainda o espaço da modernidade - não é mais a largueza da composição e as áreas contrastadas claro-escuras que tanto tinham chamado atenção dos impressionistas franceses. Van Gogh e os fauvistas, em especial Matisse (18691954), apreendem nestas estampas algo bem peculiar: as vastas superfícies sem sombras, e mais particularmente ainda as cores puras, às quais dariam um tratamento chapado de modo a assegurar uma intensidade de expressão.

A comprovação de que Van Gogh aprendeu sistematicamente com as estampas japonesas - não fosse a própria intensidade de cores puras e efeitos à maneira oriental que podemos encontrar nas suas pinturas - pode ser buscada em diversos estudos de Van Gogh que apresentam um explícito paralelo com algumas estampas japonesas da época. Entre elas, podemos citar "Chuva na Ponte" e "As Três Árvores"

A descoberta ocidental do impactante efeito das 'cores puras' pode ser associada a uma segunda leitura modernista da arte japonesa, ou pelo menos esta descoberta teria sido algo acelerada pela instigante conscientização de alguns artistas ocidentais com relação ao fato de que as artes visuais japonesas já lidavam muito mais livremente com a cor do que a pintura européia. De fato, para muitos artistas japoneses, mesmo quando envolvidos com a representação de uma cena ou objeto, não havia qualquer obrigatoriedade de se aproximar da "cor local" - isto é, da cor que determinadas figuras ou objetos teriam na sua situação de origem. Vale dizer, estes artistas se permitiam a dar um tratamento muito mais subjetivo à cor, e também buscavam superar as próprias limitações da visão humana criando um universo de cores que tinha a sua própria lógica interna, sem estarem atrelados a uma mera imitação das possibilidades cromáticas oferecidas pelo mundo circundante. A Cor era para alguns deles uma possibilidade de reconstrução de uma realidade que tinha as suas próprias regras, um elemento expressivo de alta significação. 


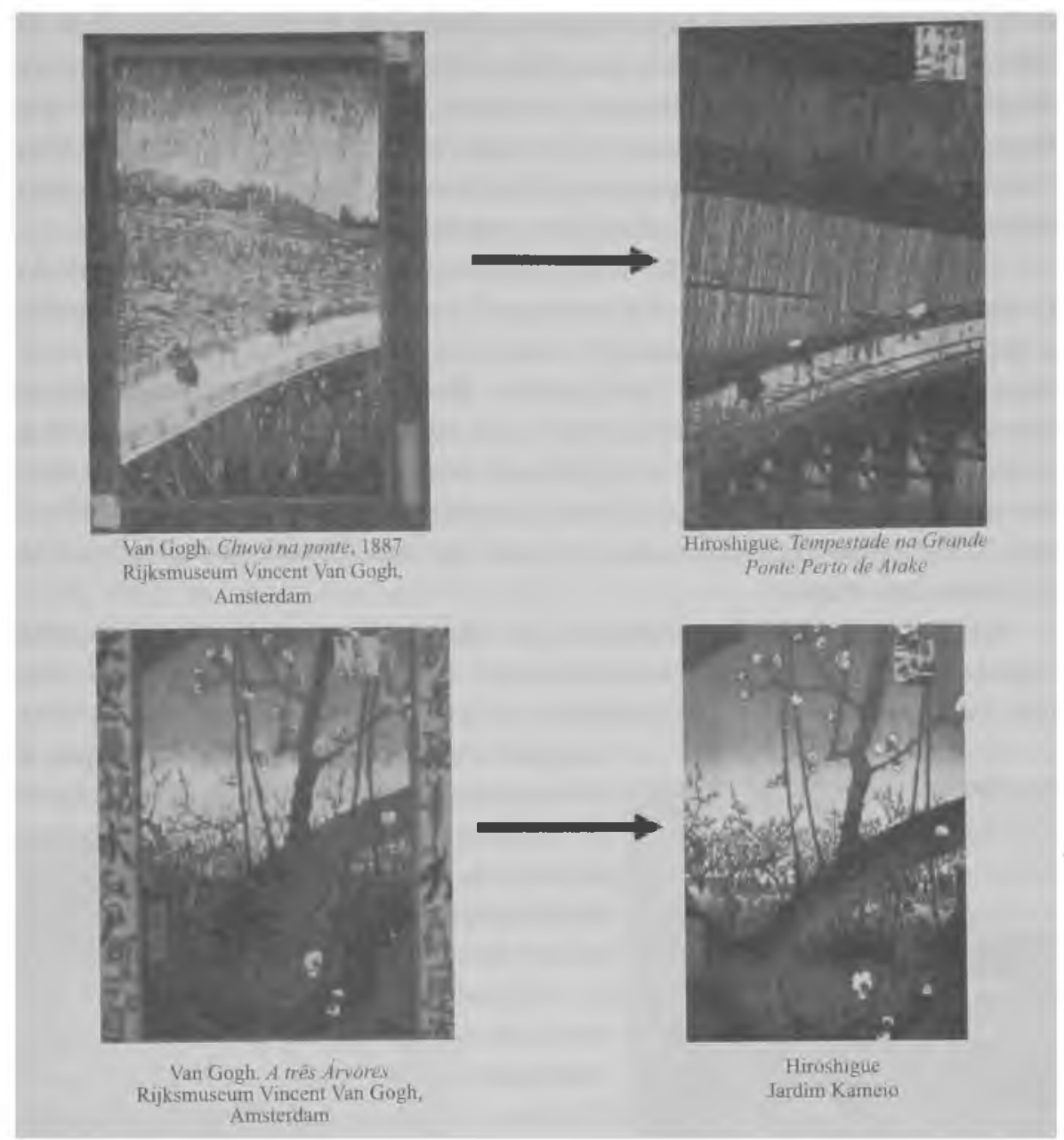

No Ocidente, esta nova postura frente à Cor começara a irromper a partir de Van Gogh e Gauguin. É verdade que, mesmo antes, já havia sido iniciada uma extraordinária pesquisa pictórica com as experiências impressionistas em torno dos efeitos de luz e cor extraídos da própria Natureza - e são bons exemplos disto as diversas representações que Monet fizera da Catedral de Rouen (1894) em diferentes momentos do dia e em condições atmosféricas diversificadas. Mas já havia pintores igualmente modernos que não mais se contentavam com os delicados matizes impressionistas habitualmente explorados por pintores como Renoir e Monet, e alguns já consideravam as paletas impressionistas um tanto monótonas ${ }^{4}$. De igual

4. "É possivel falar sobre a escola impressionista, porque os impressionistas sustentaram certos principios. Para nós, não havia nada disso, pensávamos apenas que as cores dos impressionistas eram um tanto monótonas" (WHITFIELD, 1991:11). 
maneira, muitos já não viam porque seguir os ditames da Natureza com relação às possibilidades cromáticas. Pintores como Henri Matisse, André Derain e Maurice Vlaminck vinham se interessando cada vez mais em explorar os caminhos que haviam sido abertos pelo pioneirismo de Vincent Van Gogh e de Paul Gauguin. Eles logo tenderiam a preferir francamente as paletas fortes e vibrantes, e em alguns casos a substituir a indefinição impressionista por contornos delineadamente pesados.

É extremamente significativo o papel inspirador que seria desempenhado pela arte japonesa e oriental, de modo mais geral - mas também pela então chamada "arte primitiva" dos povos africanos - num dos mais importantes movimentos artísticos do princípio do século XX: o Fauvismo. Na verdade, estes artistas já vinham amadurecendo um caminho pictórico onde se destacava de maneira bem especial a franca utilização de cores puras e uma aplicação bem mais generosa da tinta na tela, e pode-se dizer que a nova leitura da alteridade oriental em um pintor como Henri Matisse (1868-1954) desempenha aqui o papel de uma descoberta de algo que já estava dentro dele mesmo.

Matisse extrairia das estampas japonesas algo bem distinto daquela serenidade e refinamento que havia encantado os pintores impressionistas. Sua atenção se voltaria mais especificamente para as vastas superficies sem sombras

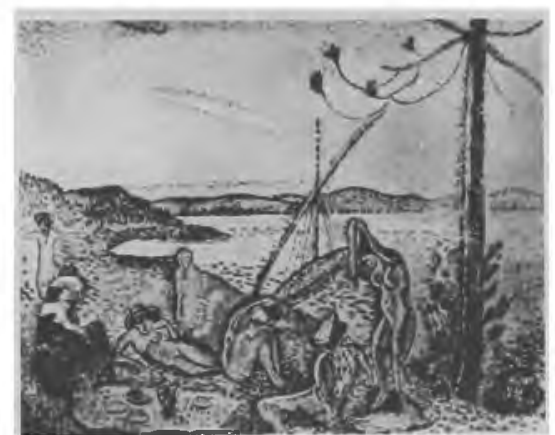

Matisse. Luxe, calme et volupté. 1904. Óleo sobre Tela. $98,3 \times 118,5 \mathrm{~cm}$ Musée National d'Art Moderne, Paris. que aparecem em algumas destas estampas, $\mathrm{e}$ obviamente para as cores puras que ali surgem de maneira franca e desimpedida. Apontase também em Matisse uma inspiração na cerâmica persa, da qual o pintor aprendera "a arte de combinar de um modo decorativo" (a expressão é do próprio pintor, em um artigo da época). Dentro deste espírito, uma tela pintada por Matisse em 1904 - "Luxo, Calma e Volúpia" - já mostra figuras nuas radicalmente simplificadas, de modo que elas terminam por assumir no conjunto uma função essencialmente decorativa. Tudo nesta tela já conspira para pôr abaixo uma longa tradição paisagística que até então havia se desenvolvido na arte ocidental.

Antes de serem percebidos como corpos femininos, as figuras de mulheres nuas que estão dispostas na tela são essencialmente formas que desempenham uma função plástica no conjunto. Formas que, por sua vez, não deixam de ser invólucros que abrigam pequenas manchas de cores puras (MULLER, 1976: 28). Da mesma maneira, a árvore, a linha da praia e o barco - dispostos na parte direita da tela desempenham fundamentalmente o papel de unificar a superfície pictórica num único plano espacial. Cada elemento nesta tela tem uma função eminentemente decorativa. 
É também interessante notar que Matisse reapropria-se neste quadro da técnica pontilhista, que havia sido desenvolvida por Seurat nos anos anteriores e que consistia basicamente em justapor pontos ou pequenas manchas de cores de modo a produzirem um efeito ótico a certa distância. $O$ pontilhismo era uma das sensações da época, e Signac - um dos aliados de Seurat nesta nova técnica pictórica - havia registrado em seu ensaio sobre a pintura moderna aquilo que logo ficou conhecido como "teoria do divisionismo da cor" (SIGNAC, 1899). Segundo esta teoria, as cores deveriam ser aplicadas em doses cuidadosamente calculadas de cores complementares.

O pontilhismo proposto pr Matisse em "Luxo, Calma e Volúpia" tinha contudo as suas singularidades. Tratava-se de um pontilhismo que explorava cores bastante fortes, e não a paleta discretamente suave e aveludada que costumava predominar nas telas de Seurat e Signac. Matisse avança aqui em novas direções, deixando que as cores ajam e reajam intensamente umas sobre as outras. Em alguns aspectos, este emblemático quadro antecipa os caminhos que logo seriam seguidos por Matisse em direção a uma arte que a si mesma impunha uma meta tão decorativa quanto a que $o$ pintor apreendera das gravuras japonesas e da cerâmica persa, e que cada vez mais se concentraria em explorar um novo e vivo universo de cores.

"Luxo, Calma e Volúpia" chamou imediatamente a atenção de André Derain, Maurice Vlaminck e outros jovens pintores que ansiavam por uma renovação pictórica através de novas possibilidades de tratamento da Cor. Seguindo nesta nova direção,

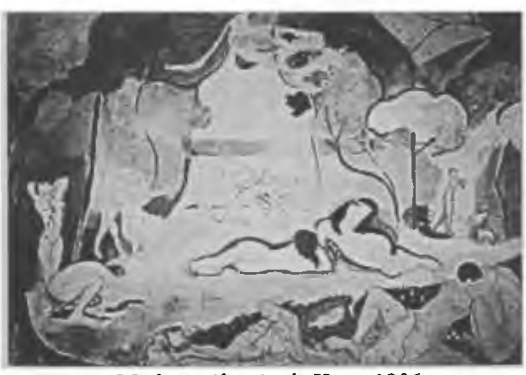

Matisse. Alegria de Viver, 1906 Óleo sobre Tela. $175 \times 241 \mathrm{~cm}$. Bames Fundation os Fauvistas realizariam a sua célebre exposição em 1905 - marco de um movimento que, embora de curtíssima duração, teria profunda repercussão na arte moderna. Matisse, o principal nome, seguiria explorando de maneira cada vez mais audaciosa as cores puras e efeitos decorativos, freqüentemente evocando um padrão gravurista japonês (mas também eventualmente inspirado na tapeçaria persa) de tratamento da cor e do desenho.

A rigor, um dos primeiros quadros de Matisse que conseguem concretizar mais efetivamente um verdadeiro diálogo com o padrão japonês, ultrapassando as diversas abordagens neo-impressionistas de que o pintor até então se valera - inclusive a técnica pontilhista que vimos em "Luxo, Calma e Volúpia" - foi o impressionante quadro intitulado "Alegria de Viver" (1906). Apesar da semelhança temática entre os dois quadros - uma cena ao ar livre onde diversos nus femininos algo esquematizados integram-se decorativamente às imagens naturais - este novo quadro de Matisse introduzia definitivamente um novo estilo.

A partir de agora a forma de cada objeto ou figura será bem definida por um contorno visível e delineado, às vezes reforçado por um arabesco que flexibiliza o contorno sem no entanto deixar de mantê-lo bem definido. Conforme a figura 
esteja contraposta a um fundo mais claro ou mais escuro, a linha de contorno pode ser reforçada ou afinada, como pode ser constatado com o contorno firme dos nus centrais que se inserem em um ambiente de maior luminosidade ou com o contorno delgado das figuras dispostas sobre o fundo mais escuro do canto inferior direito. Esta maneira ponderada de lidar com a espessura das linhas de contorno de modo a sugerir volumes, e também os caminhos sinuosos que a linha percorre de maneira a sugerir um novo padrão de espaço - não mais perspectivado - é tipicamente japonesa.

Não fossem estas novas conquistas relativas ao Desenho, o que Matisse propõe com este quadro é também uma continuidade em relação àquela nova forma de tratamento da Cor. Tal como ocorria nas estampas japonesas, a cor mostra-se aqui aplicada em grandes extensões de superfícies planas. O Fauvismo de Matisse começa a se afirmar neste momento a partir de seus dois pilares essenciais: a Cor e o Desenho.

Para além disto, e confirmando um caminho que já vinha se afirmando anteriormente, cada vez mais o que importa para Matisse é o tratamento decorativo. Longe ficou qualquer intenção de verossimilhança à maneira clássica ou mesmo neoimpressionista, e isto fica claramente constatado quando examinamos os tamanhos das figuras de nus que se espalham na tela e definem os diversos planos. Os dois nus femininos centrais são maiores que os demais, não em decorrência da posição de maior ou menor proximidade que ocupam no espaço em relação a um observador. $O$ tamanho de cada figura é gerido pela sua função decorativa. À direita, à esquerda ou à frente veremos figuras diminutas ou um pouco maiores. No centro geométrico do quadro uma pequenina roda de seis dançarinos. Esta roda de dançarinos que giram de mãos dadas, aliás, será retomada posteriormente em um dos quadros de Matisse que se tornariam mais célebres - a tela que seria denominada "A Dança" (1908), e que também traz as suas referências e alusões orientais.

Um vislumbre sobre a rica produção de Matisse nas primeiras décadas do século permite salientar, aliás, que em algumas fases de sua produção pictórica Matisse não se ateve a um único estilo. Assim, entre os anos de 1906 e 1907, que podem ser indicados como o período apoteótico e terminal do Fauvismo, veremos Matisse experimentar indistintamente as superfícies lisas e uniformes de cores puras - como nas obras que atrás associamos a uma inspiração oriental - e as composições elaboradas com diversidades de manchas, linhagem de experiências pictóricas que para o caso de Matisse haviam sido iniciadas com o polêmico quadro "A Mulher do Chapéu" (1905). Este caminho, na verdade, é uma herança recebida dos Impressionistas e de Cézanne, só que reelaboradas com uma especial liberdade que é já puro Matisse.

Estes são alguns exemplos do diálogo de Henri Matisse com a alteridade oriental - seja ela a das estampas japonesas, a da arte persa ou a da simbologia chinesa. Assim como ele, diversos outros artistas ocidentais da primeira metade do século 
puderam encontrar na arte oriental uma constante fonte de renovação - e seria questão de levantar um longo inventário com vistas a identificar estas influências, implícitas ou explícitas, nos mais diversos movimentos que começam a surgir entre as últimas décadas do século XIX e meados do século XX. Neste sentido, uma reapropriação cultural como a das gravuras japonesas pertence tanto à história do Impressionismo e do Neo-impressionismo - através de Monet, Sisley, Toulouse-Lautrec ou Degas - como à curta história da Art Nouveau, estilo decorativo que atinge seu apogeu entre a última década do século XIX e o princípio do século XX e que, associado à Arquitetura, entrelaça as influências dos objetos japoneses e chineses a uma retomada neo-rococó de uma das correntes estilísticas do século XVIII.

Os artistas ligados à Art Nouveau - em áreas as mais diversas como a Pintura Decorativa, a Arquitetura, o Design, a Cerâmica, ou a confecção de objetos funcionais como copos e cristais - oferecem inúmeros exemplos da moda japonesa e chinesa que invade a Europa e a América em torno da passagem do século XIX ao século XX. $\mathrm{Na}$ Ilustração, as referências são Eugéne Grasset e Georges Auriol. Trabalhos em vidro tornaram-se a especialidade de artistas como o francês Émile Gallé ou o tcheco Loetz, e através deles e de cerâmicas como as de Jean Carriès e Clément Massier, mais uma vez temos o retorno de um imaginário oriental - agora através de objetos refinados de diversos tipos.

O que une os artistas nouveau ao padrão presente nos objetos orientais é o predominio de um estilo floreado, onde se destacam a linha curva e as formas orgânicas inspiradas em folhagens, flores, cisnes, libélulas, labaredas e outros elementos naturais ou telúricos. São ainda os arabescos lineares e cromáticos, mostrando clara preferência pelos ritmos baseados na curva e suas variantes (espiral, voluta), que

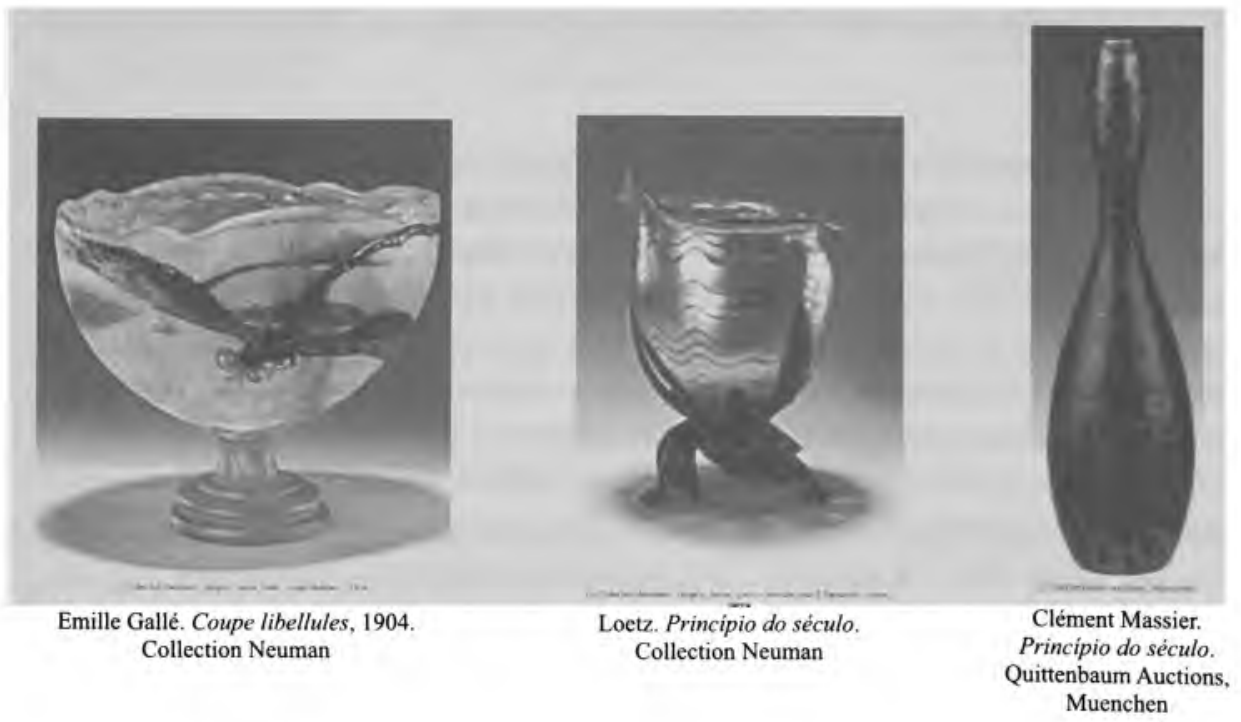


permitem a imediata associação entre o novo estilo e o imaginário oriental, uma referência que muitos dos artistas nouveau não se incomodavam de explicitar.

Exemplos de Arquitetura associáveis à Art Nouveau e à influência oriental também podem ser fartamente encontrados nos projetos do arquiteto belga Victor Horta (1861-1947). Como ele, e para citar mais alguns artistas europeus que se deixaram influenciar pela estética oriental fora da França, será importante destacar que os artistas americanos e ingleses de fins do século XIX também não foram indiferentes ao modelo visual japonês. Por ora será bastante citar o norte americano James McNeill Whistler (1834-1903) - com seus característicos "noturnos", que extraíam das gravuras japonesas inspiração para delicados padrões visuais - ou ainda o ilustrador inglês Aubrey Beardsley (1872-1898), com seus elegantes desenhos em branco e preto.

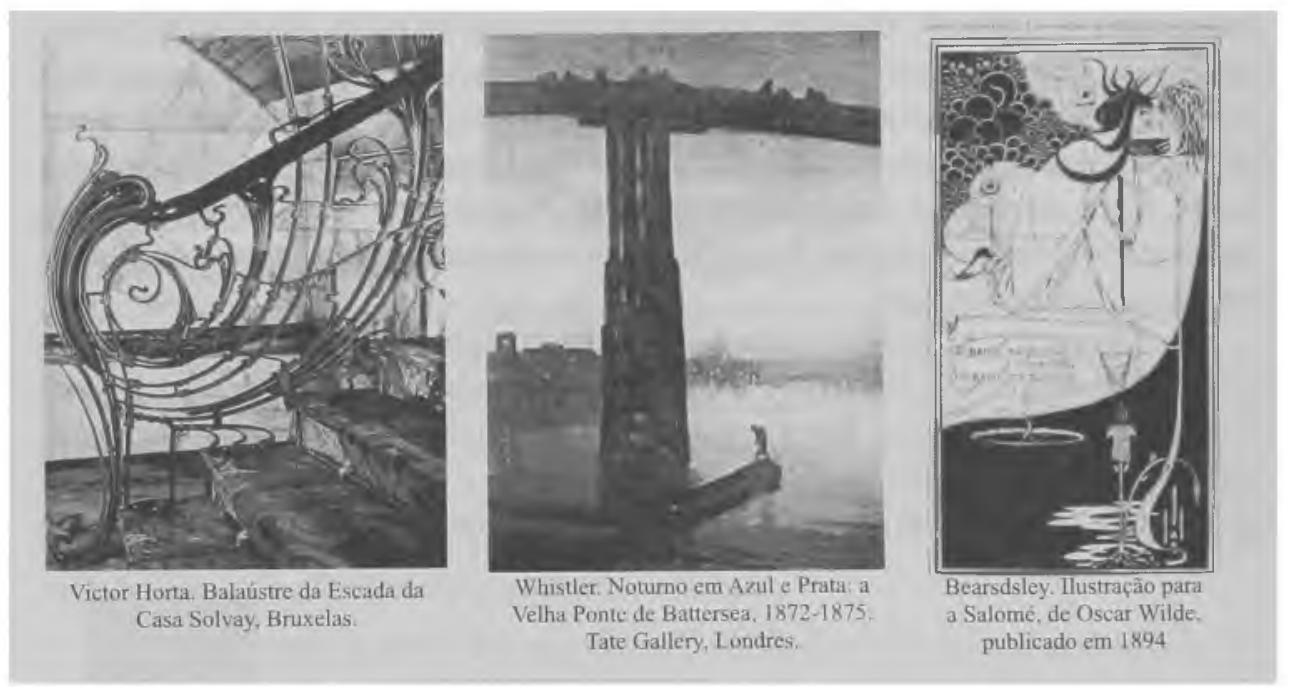

A arte produzida no Oriente seguiria influenciando a renovação pictórica do ocidente em outros momentos. É conhecida a influência do abstracionismo informal do artista japonês Kosaka Gajin (1877-1953) através dos Estados Unidos, ajudando a consolidar a tendência americana do Expressionismo Abstrato que foi levada adiante por pintores como Pollock (1912-1956) e Willem de Kooning. Por fim, se foi possível falar da influência japonesa na moderna arte ocidental, poderíamos ter discutido também o outro caminho: como o Ocidente influencia a arte japonesa. A produção artística do período Meiji, entre 1868-1912, documenta a influência de um tradicional figurativismo ocidental na arte japonesa daquele período. O próprio Hokusai 17601849 , que viveu antes do período Meiji e é consensualmente considerado um dos maiores artistas da história da arte japonesa, teria adotado a certa altura a perspectiva, assim que se deu conta de como ela era aplicada no Ocidente. E, num futuro além, os mais modernos artistas japoneses também se inspiraram na arte ocidental mais 
inovadora. $\mathrm{O}$ jogo de influências entre culturas, portanto, é recíproco neste caso. Mas isto já fugiria ao tema que estamos aqui abordando, que é o do papel da Alteridade japonesa na renovação da arte ocidental, e não a questão inversa.

A influência japonesa na Arte Moderna ocidental, em suas diversas modalidades da pintura à cerâmica e à arquitetura, é portanto bastante evidente em diversos momentos do desenvolvimento da arte ocidental moderna. Para considerar outros campos de expressão, seria também possível indicar, para o âmbito do Cinema, a inspiração primordial das montagens de Eisenstein (1898-1948) nos já mencionados ideogramas chineses - eles mesmos considerados pelo cineasta russo como uma espécie de "montagem" - e também no kabuki, que era uma forma estilizada de drama teatral desenvolvida no Japão. Por fim, para ressaltar um último exemplo, será oportuno lembrar que a própria Arquitetura ocidental moderna de a partir dos anos 1980, a seu tempo, também trouxe à tona um interesse pela tradicional arquitetura japonesa.

Estes diversos exemplos apenas reforçam a demonstração da tese de que o que os artistas e escritores modernos buscaram no Oriente e em outros territórios de alteridade foi uma possibilidade efetiva de renovação dos seus meios, mais do que o mero interesse temático que já aparecia na arte romântica ou mesmo em períodos anteriores ao século XIX. Também podemos perceber aqui-embora reconhecendo que o aprofundamento desta questão nos levaria para muito além dos limites deste ensaio - que o interesse de renovação a partir da Alteridade foi um fenômeno cultural mais amplo, abarcando não apenas as Artes Visuais como também a Poesia, a Literatura, a Arquitetura, a Música e o Cinema. Neste sentido, não apenas nas artes visuais, como também em outras modalidades de expressão artística, a dívida da moderna arte ocidental para com as alteridades e modos artísticos de expressão tipicamente orientais - em especial japoneses - adquire especial evidência e significação.

\section{Bibliografia}

HASHIMOTO, Madalena. Pintura e Escritura do Mundo Flutuante: Hishikawa Moronobu e ukiyo-e Ihara Saikaku e ukyo-zôshi, São Paulo: Hedra, 2002.

MACHADO, Sonia Maria Farria. Presença da Arte Japonesa na obra de Monet, Rio de Janeiro: Arte Final, 1988.

MULLER, Joseph Emile. O Fauvismo, São Paulo: Verbo, 1976.

PEDROSA, Mário. "Japão e Arte Ocidental" in Otília Arantes (org.), Modernidade Cá e Lá-textos escolhidos. São Paulo: EDUSP, 2000.

SAID, Edward. Orientalismo - o Oriente como Invenção do Ocidente. São Paulo: Companhias das Letras, 2001. 
SIGNAC. De Eugène Delacroix ao Neo-impressionismo. Paris: Ed. De la Revue Blanche, 1899.

STANGOS, N. (org.), Conceitos da Arte Moderna. Rio de Janeiro: Jorge Zahar, 1991.

WHITFIELD, "Fauvismo" in Nikos STANGOS (org.), Conceitos da Arte Moderna, Rio de Janeiro: Jorge Zahar, 1991, p.11 e ss. 